\title{
Modelling of speleothems failure in the Hotton cave (Belgium). Is the failure earthquake induced?
}

\section{J.F. Cadorin ${ }^{1}$, D. Jongmans ${ }^{2}$, A. Plumier ${ }^{1}$,T. Camelbeeck ${ }^{3}$, S. Delaby ${ }^{4} \&$ Y. Quinif}

1 University of Liège, Chemin des chevreuils, 1 - B-4000 Liège 1, Belgium; e-mail: jf.cadorin@ulg.ac.be, a.plumier@ulg.ac.be

2 Laboratory of Geophysical Prospecting, Liège University, Bat. B19, B-4000 Liège; e-mail:djongmans@ulg.ac.be

3 Royal Observatory of Belgium, avenue circulaire 3, B-1180 Bruxelles; e-mail:thierry.camelbeeck@oma.be

4 Centre d'Etudes et de Recherches Appliquées au Karst (CERAK), Faculté Polytechnique de Mons, Rue de Houdain, 9, B-7000 Mons;

e-mail:quinif@fpms.ac.be, serge.delaby@fpms.ac.be

Manuscript received: July 2000; accepted: April 2001
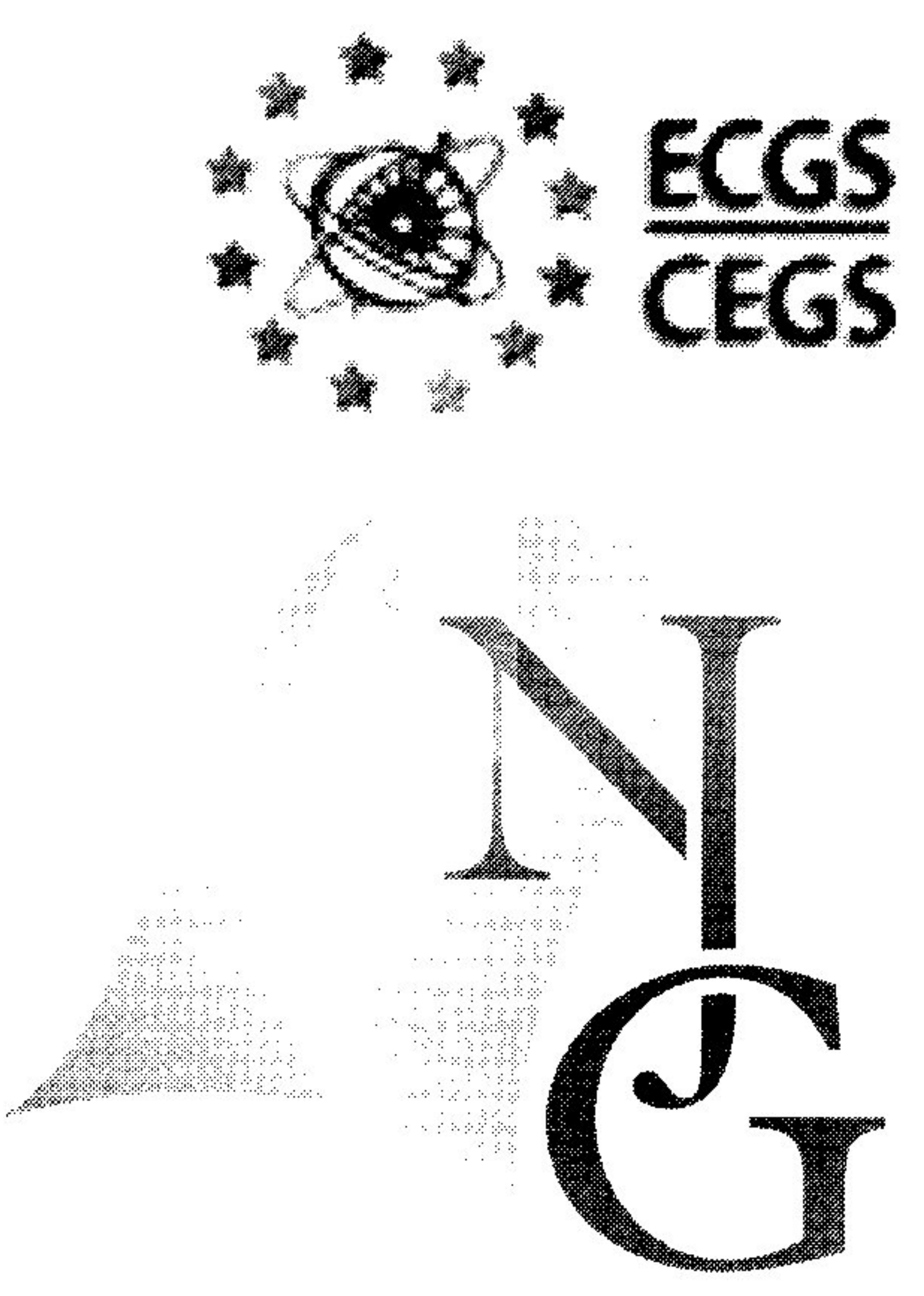

\begin{abstract}
To provide quantitative information on the ground acceleration necessary to break speleothems, laboratory measurements on samples of stalagmite have been performed to study their failure in bending. Due to their high natural frequencies, speleothems can be considered as rigid bodies to seismic strong ground motion. Using this simple hypothesis and the determined mechanical properties (a minimum value of $0.4 \mathrm{MPa}$ for the tensile failure stress has been considered), modelling indicates that horizontal acceleration ranging from $0.3 \mathrm{~m} / \mathrm{s}^{2}$ to $100 \mathrm{~m} / \mathrm{s}^{2}(0.03$ to $10 \mathrm{~g})$ are necessary to break 35 broken speleothems of the Hotton cave for which the geometrical parameters have been determined. Thus, at the present time, a strong discrepancy exists between the peak accelerations observed during earthquakes and most of the calculated values necessary to break speleothems. One of the future research efforts will be to understand the reasons of the defined behaviour. It appears fundamental to perform measurements on in situ speleothems.
\end{abstract}

Keywords: Damages, Earthquake, Mechanical properties, Speleothems.

\section{Introduction}

The idea that speleothems may record strong earthquakes seems to be widely accepted by geologists studying natural caves. During the recent years, many observations have been done in numerous caves in Europe, interpreting observed deformations as tectonic ones. In this context, the observations are interesting because they can provide indirect evidence of past large earthquakes (Bini et al., 1992 ; Delaby, 1999 ; 2001 ; Forti \& Postpischl, 1979, a, b; 1980 ; 1984 ; 1986 ; 1988a ; 1988b ; Gilli, 1986 ; 1999 ; Gilli et al., 1999; Lemeille et al., 1999 ; Moretti \& Vulcano, 1999; Postpischl et al., 1991 ; Quinif, 1996). Unfortunately, to our knowledge, there are very few direct, if they exist, observations of broken speleothems during strong earthquakes.
Thus, to establish the seismic origin of the deformed speleothems, it is necessary to work in different ways: (i) to look for recent seismothems (a seismothem is defined as a speleothem potentially broken by a seismic event, Delaby, 2001) linked to present day earthquakes; in this way, Gilli et al. (1999) provide the first trying of quantitative analysis for a moderate earthquake in the Pyrenees. (ii) to provide detailed description of 'stalagmite cemeteries'; (iii) to correlate the deformational events in different caves; (iv) to model the mechanical behaviour of speleothems in their natural condition in the caves.

We undertook a detailed study of the mechanical properties of speleothems to determine if ground motions generated during strong earthquakes can break them. We used samples of stalagmite broken in the Hotton cave (Belgium). The cave of Hotton (fig. 1 for 


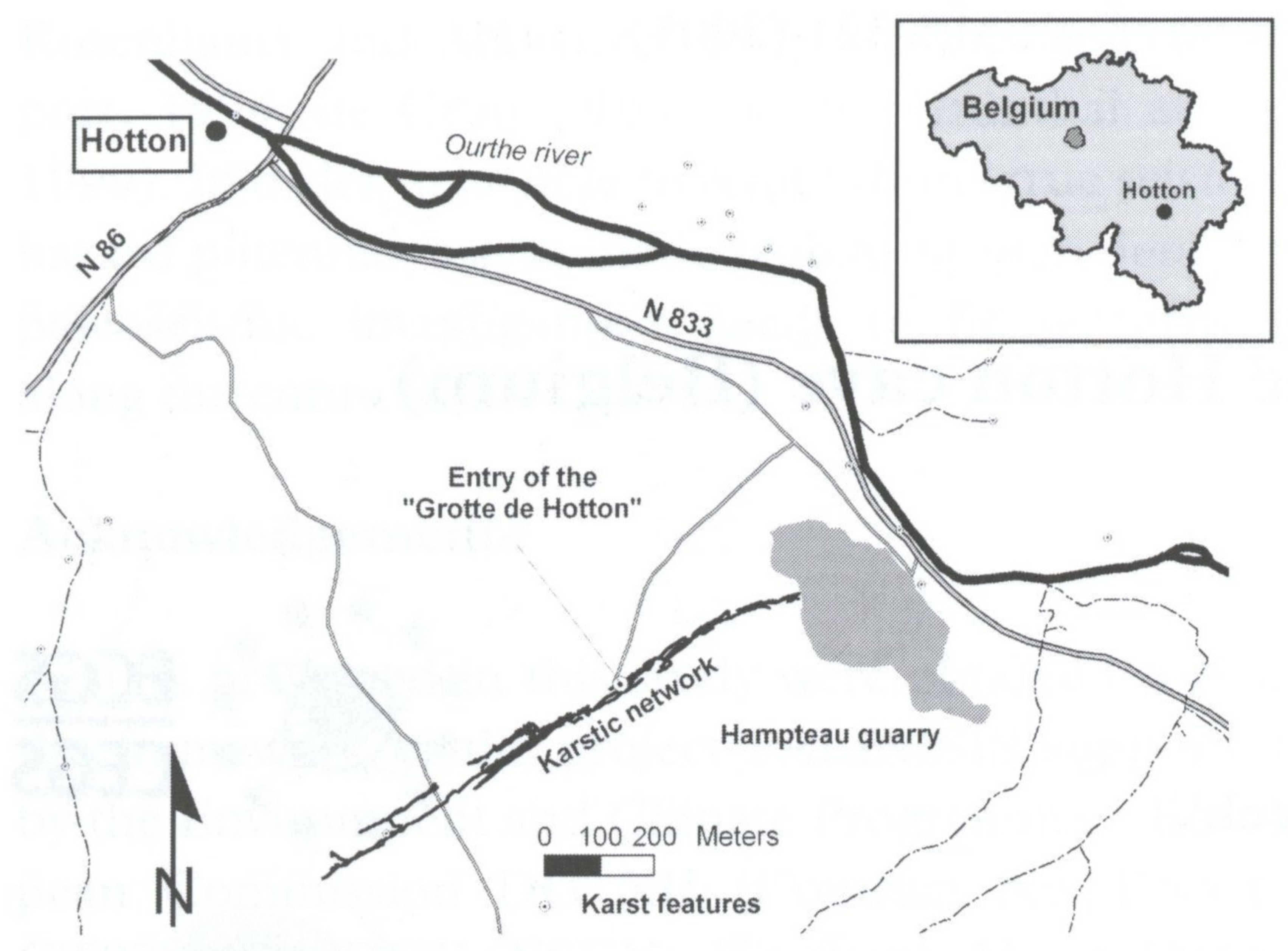

Fig. 1. Localisation of Hotton.

its location) is an ideal study site. It develops in Givetian limestone with sub-vertical, inverse layering of constant orientation. The cave is the down-stream part of one of the most impressive sink - resurgence system in Belgium. The cave of Hotton was discovered in a quarry in 1958 and was immediately closed for protection. At the present time, the cave develops $5 \mathrm{~km}$ of galleries. Up-stream, the galleries are preserved from human depredation by a number of doors and sumps.

The cave of Hotton is a typical example of a multilevel cave. The different levels of the cave are linked with the evolution of the Ourthe River. The upper level, older, shows deformed and broken speleothems. Delaby (2000) provides field evidence that the cause of the speleothems break or deformation could be of seismic origin. In this study, we examined candle shaped stalagmites having particular morphological and environmental characteristics. The ideal shape of the stalagmite is a cylinder with a rather constant diameter and with the gravity centre above the base (contact point) of the stalagmite. The pieces of the broken stalagmite must be soldered and the stalagmite must have grown on a stable substratum.

The static and dynamic behaviours of the speleothem materials have been firstly studied by laboratory testing. With the help of the material properties and the in-site geometry measurement, the maximum acceleration of the earthquake which could have caused the speleothem failure has been evaluated.

\section{Mechanical properties of speleothems}

Various laboratory tests have been performed on the speleothems taken in the Hotton cave in order to determine their mechanical properties.

The mean value of the specific mass $\rho$ of the speleothems is $2500 \mathrm{~kg} / \mathrm{m}^{3}$. The Young's modulus $\mathrm{E}$ is $22000 \mathrm{MPa}$. The variation around these values is weak. The resistance in simple compression is between 15 and $38 \mathrm{MPa}$, while the tensile resistance obtained from Brazilian tests is ranging between 1.5 and $2 \mathrm{MPa}$.

The failure tensile stress of the speleothems has also been evaluated by static and dynamic bending tests on some specimens of speleothems and one fatigue test has been made as well. Figure 2 and Photo 2 show a schematic view of the testing apparatus used for the bending tests.

Seven static bending tests have been performed on specimens sampled from 4 broken speleothems (Photo 1 shows speleothems $\mathrm{n}^{\circ} 5891$, broken in three parts, sample 5891.1, 5891.2 and 5891.3). The tensile failure stresses deduced from these tests are shown in Table 1.

The mean value and the standard deviation of these tensile failure stresses are 1.94 and $0.71 \mathrm{MPa}$,

Table 1. Tensile failure stresses from static bending tests.

\begin{tabular}{ll}
\hline Sample & Failure stress $[\mathrm{MPa}]$ \\
\hline A1 & 0.64 \\
\hline A3.1 & 2.73 \\
A3.2 & 2.75 \\
\hline B3.1 & 2.10 \\
B3.2 & 1.44 \\
\hline 5891.1 & \\
5891.2 & 2.32 \\
5891.3 & 1.63 \\
\hline
\end{tabular}

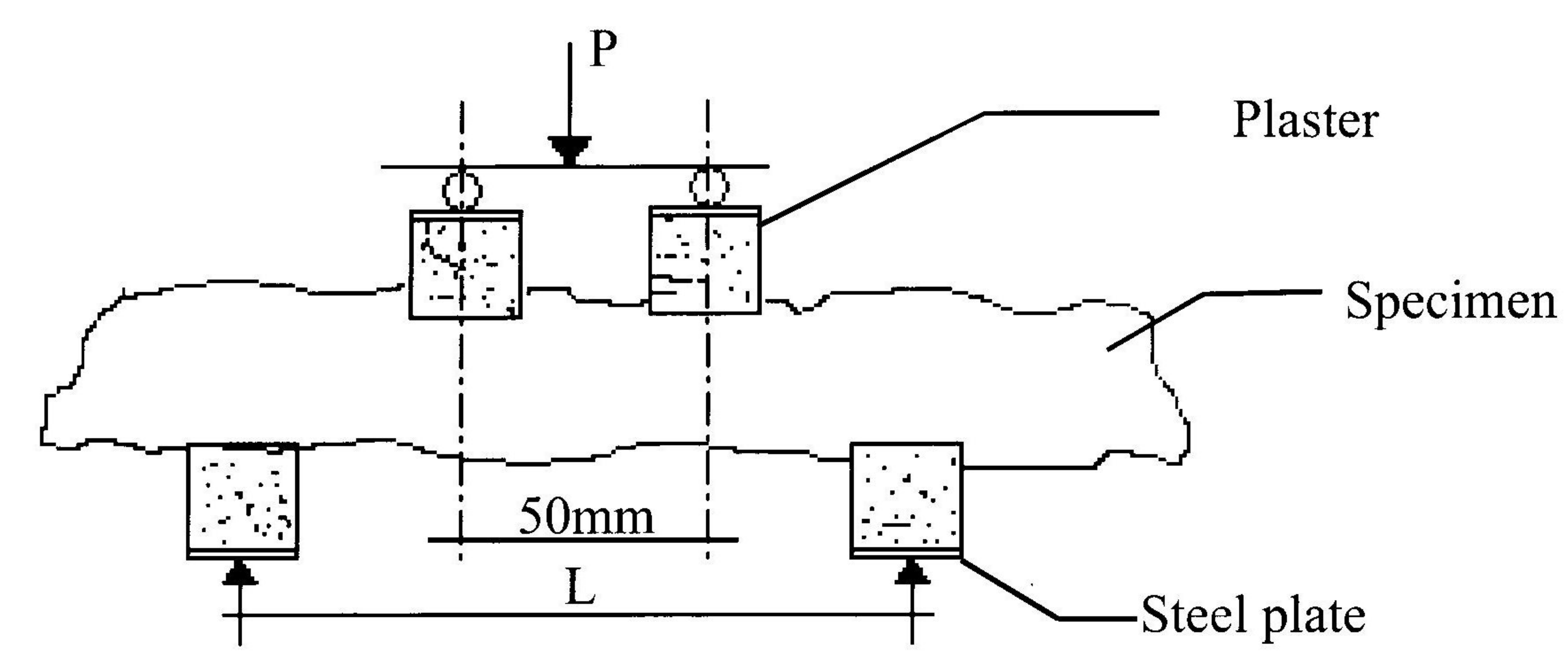


respectively, with a minimum value of $0.64 \mathrm{MPa}$. In a second phase, the effect of the load velocity has been studied by comparing the results of 3 static tests (with a displacement rate of $510^{-4} \mathrm{~mm} / \mathrm{s}$ ) and 5 dynamic tests (with a displacement rate of $5 \mathrm{~mm} / \mathrm{s}$ ) on two speleothems. The value of $5 \mathrm{~mm} / \mathrm{s}$ corresponds to a displacement rate which can reasonably be expected during an earthquake. The tensile failure stress deduced from these tests, as well as the mean values, are shown in Table 2.

Table 2: Dynamic bending tests.

\begin{tabular}{lll}
\hline Sample & $\begin{array}{l}\text { Displacement rate } \\
{[\mathrm{mm} / \mathrm{s}]}\end{array}$ & $\begin{array}{l}\text { Failure stress } \\
{[\mathrm{MPa}]}\end{array}$ \\
\hline $6186 B / 1$ & $510^{-4}(1)$ & 0.60 \\
$6186 \mathrm{C} / 1$ & $510^{-4}(1)$ & 0.42 \\
\hline
\end{tabular}

Mean -static (6186) : 0.51

\begin{tabular}{lll}
\hline $6186 \mathrm{~A}$ & 5 & 0.81 \\
$6186 \mathrm{~A} / 2$ & 5 & 0.82 \\
$6186 \mathrm{~B} / 2$ & 5 & 0.69 \\
$6186 \mathrm{C}$ & 5 & 0.82
\end{tabular}

Mean -dynamic (6186): 0.79

\begin{tabular}{lll}
\hline $6187 / 1$ & $510^{-4}(1)$ & 1.29 \\
6187 & 5 & 1.49 \\
\hline
\end{tabular}

(1) static tests are in italic.

One fatigue test has also been performed on a sample from the speleothem $n^{\circ} 6186$. Considering a failure stress of $0.7 \mathrm{MPa}$, the failure load has been estimated to $F_{u}=2400 \mathrm{~N}$. The mean value of the load is then set to half of the estimated failure load of the speleothem in bending, i.e. $F_{\text {mean }}=1200 \mathrm{~N}$. The force variation is set to 80 percent of the estimated failure load, i.e. $\Delta \mathrm{F}=2000 \mathrm{~N}$. The load is applied with a frequency of $1 \mathrm{~Hz}$ ( 1 cycle per second) considered to represent a real earthquake. Figure 3 shows the applied load function of time. The failure of the specimen has been attained after 1411 cycles, a number which is much higher than expected during one or several earthquakes.

\section{Conclusions on the mechanical properties}

The failure tensile stress values obtained by bending of broken speleothems from the Hotton cave range between 0.4 and $2.7 \mathrm{MPa}$. However, the range on the results obtained on samples coming from the same speleothem is weaker.

The tensile stress obtained in dynamic tests is slightly higher then in static tests but it has a lower in-

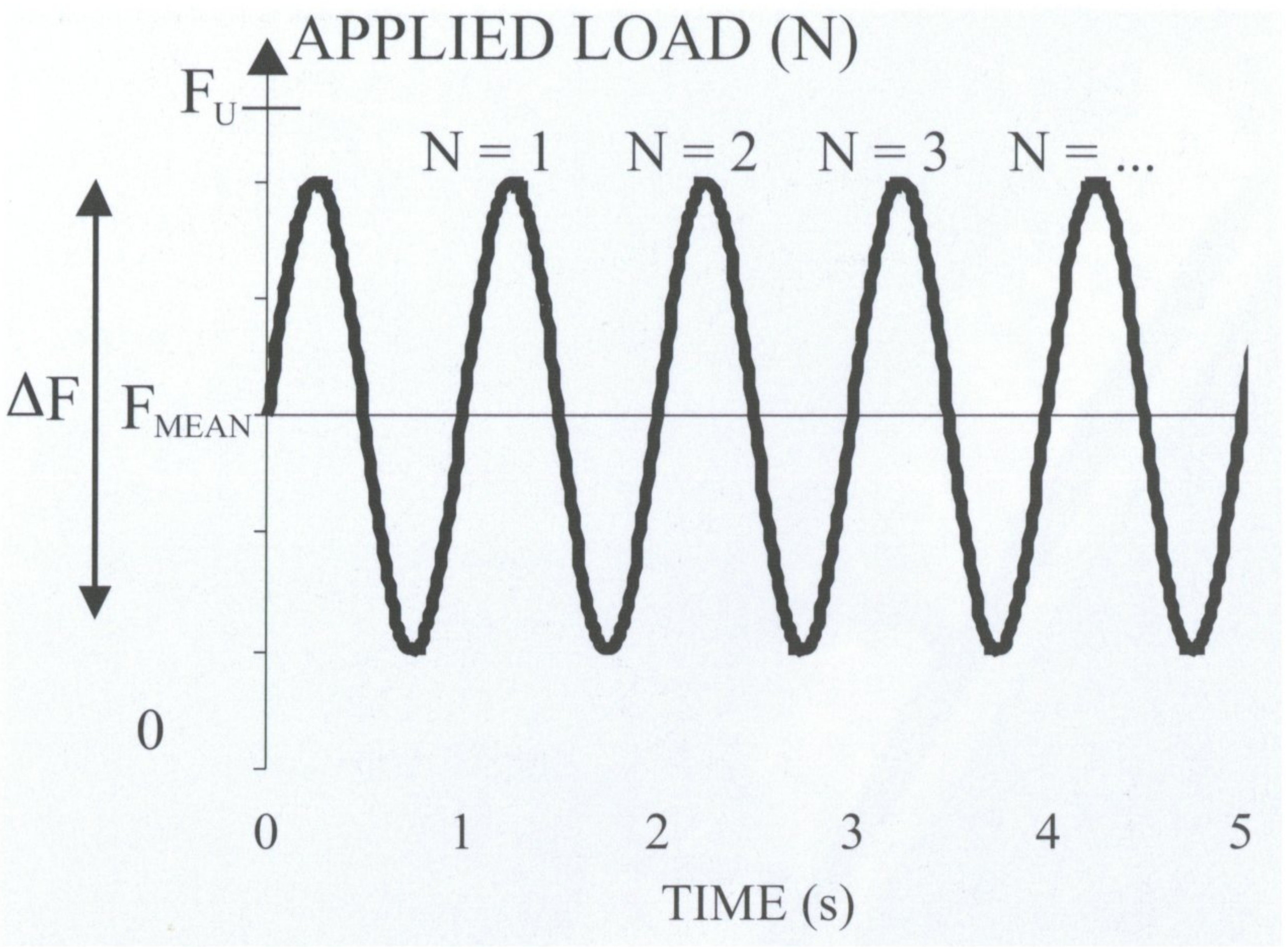

Fig. 3. Applied load function of time in the fatigue test.

fluence then the scattering of the static tensile resistance of different speleothems.

The test fatigue resistance is high i.e. more number of cycles then an actual speleothem during one or several real earthquakes.

\section{Estimation of the ground accelleration leading to the failure of broken speleothems in Hotton Cave}

The geometry of 34 broken speleothems in the Hotton cave have been reconstituted (Delaby, 2001). The available data (Table 3) are the height $\mathrm{H}$ of the reconstituted fallen part and the diameter $\mathrm{D}$ of the failure section which is considered circular. The speleothems are considered as cantilever beams of height $\mathrm{H}$ and with a constant circular section of diameter D (Figures 4 and 5).

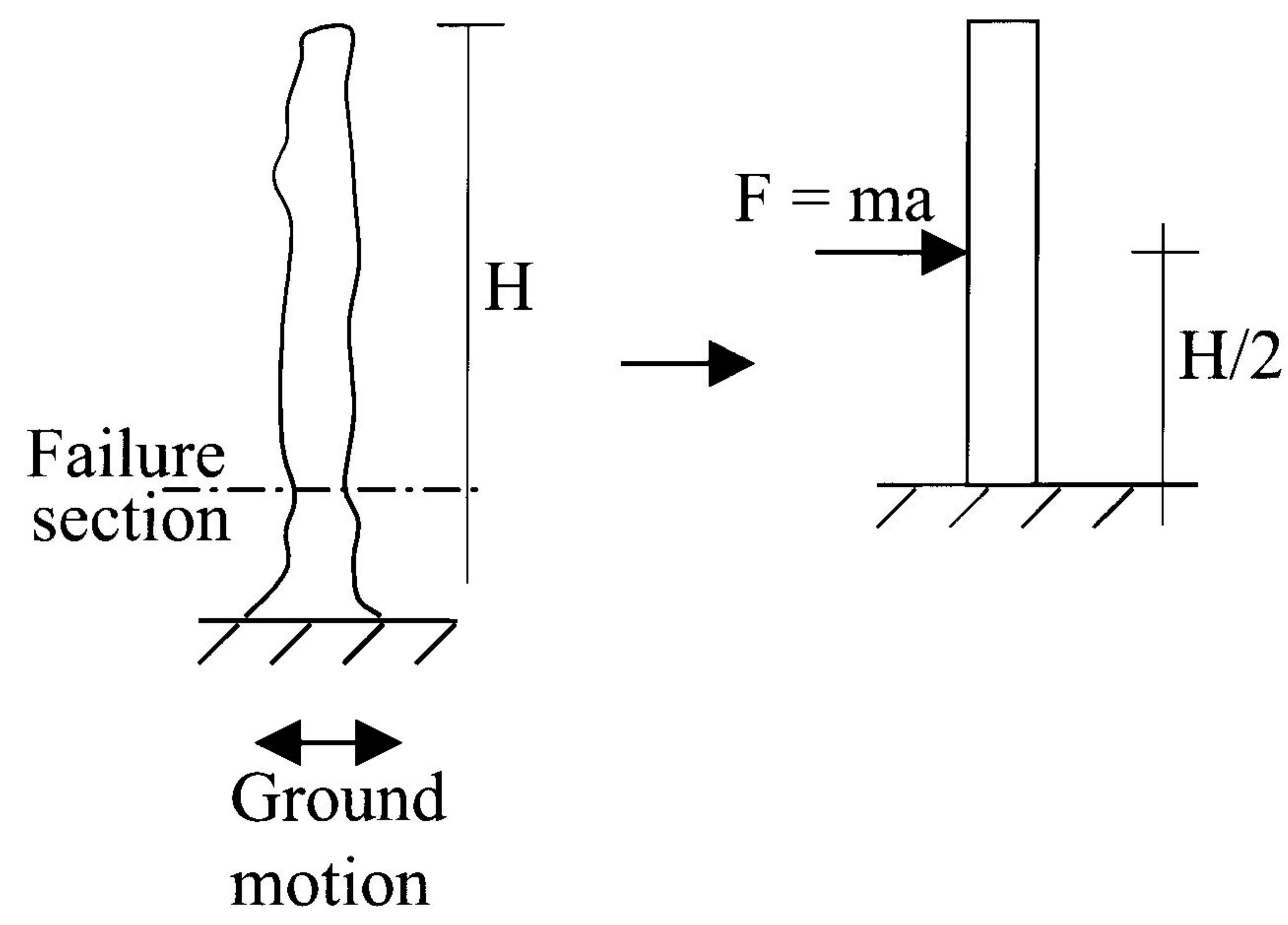

Fig. 4. Elevation view of a speleothem and model.

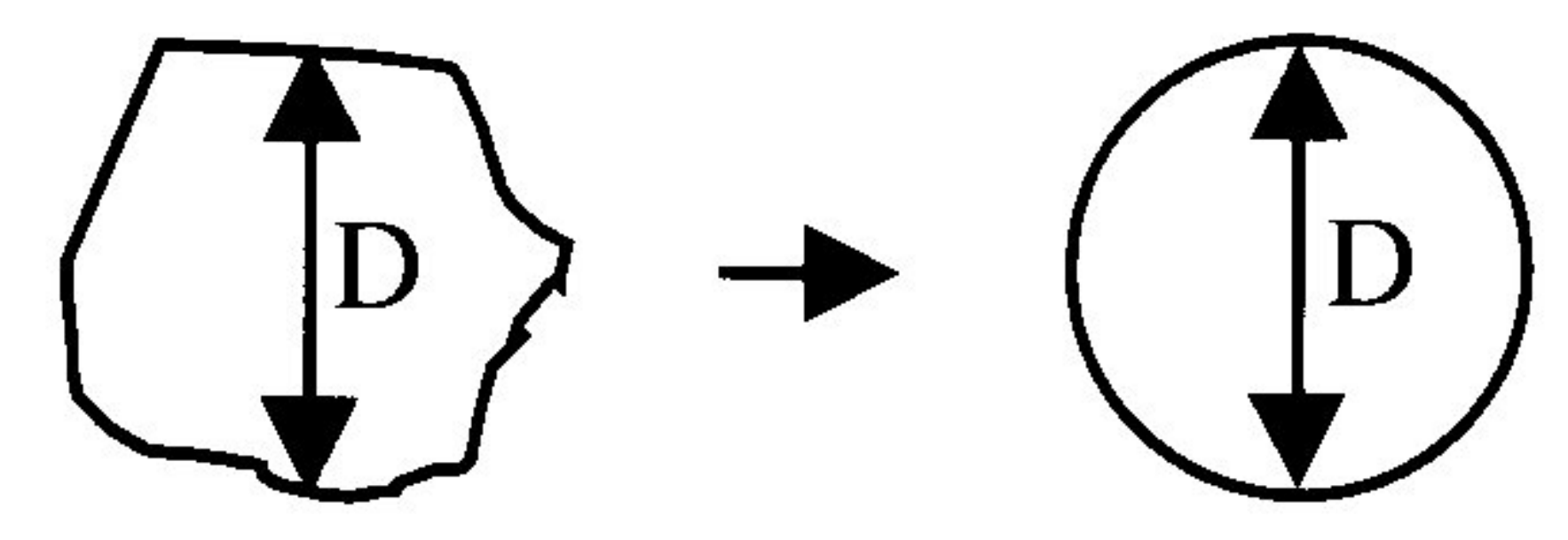

Fig. 5. Failure section and model. 


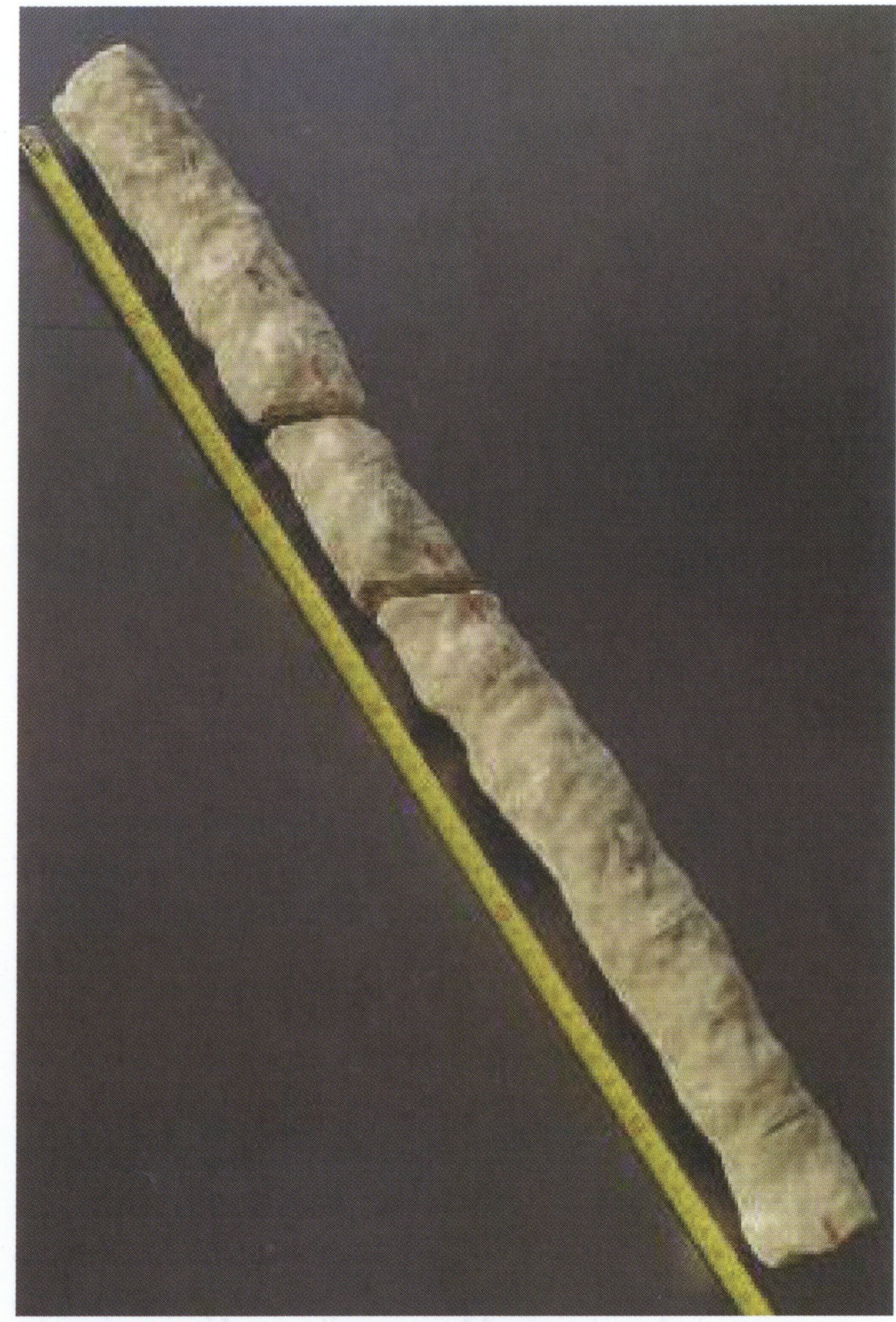

Photo 1. Speleothem $\mathrm{n}^{\circ} 5891$ (samples 5891.1, 5891.2 and 5891.3).

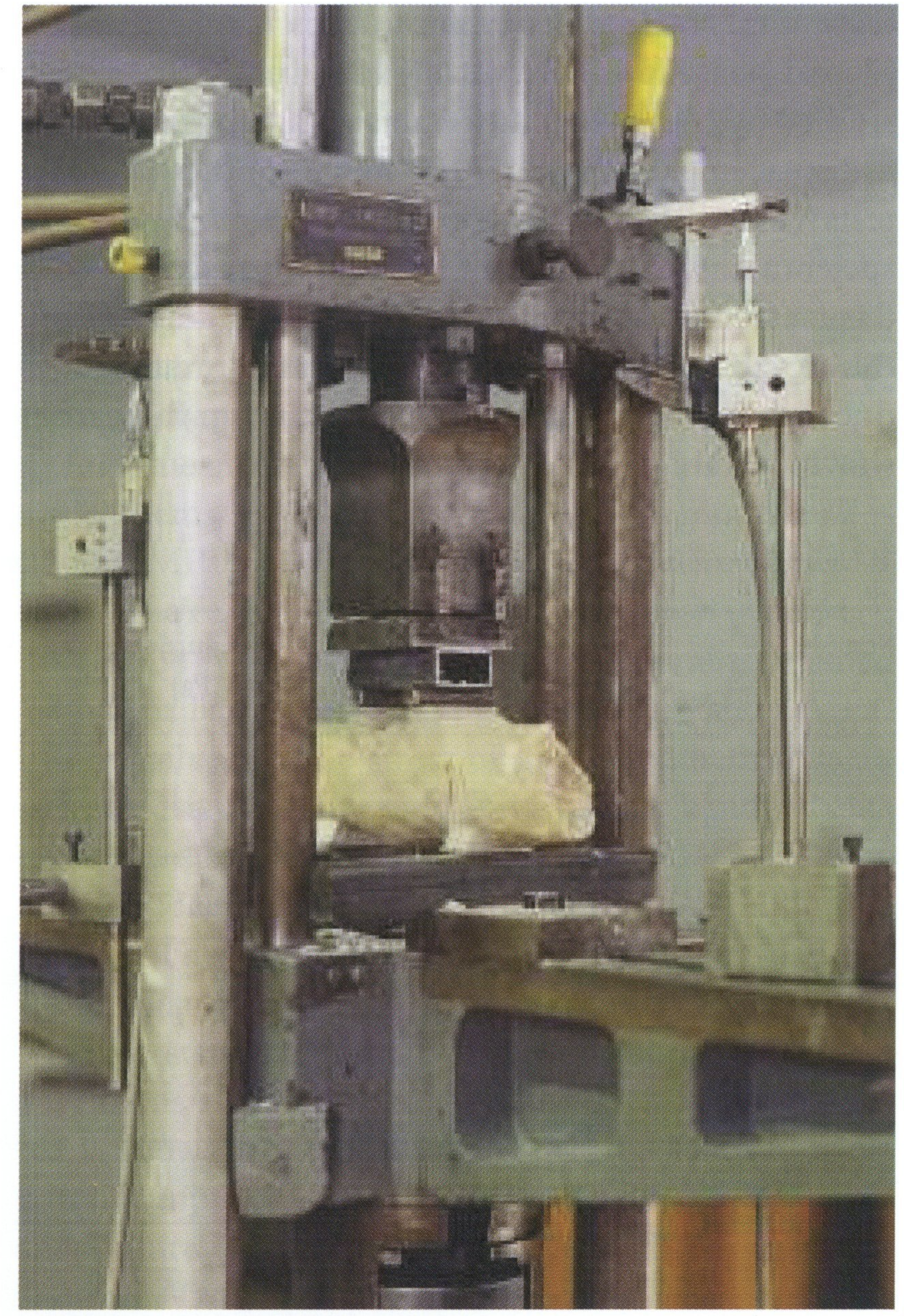

Photo 2. Bending test apparatus.

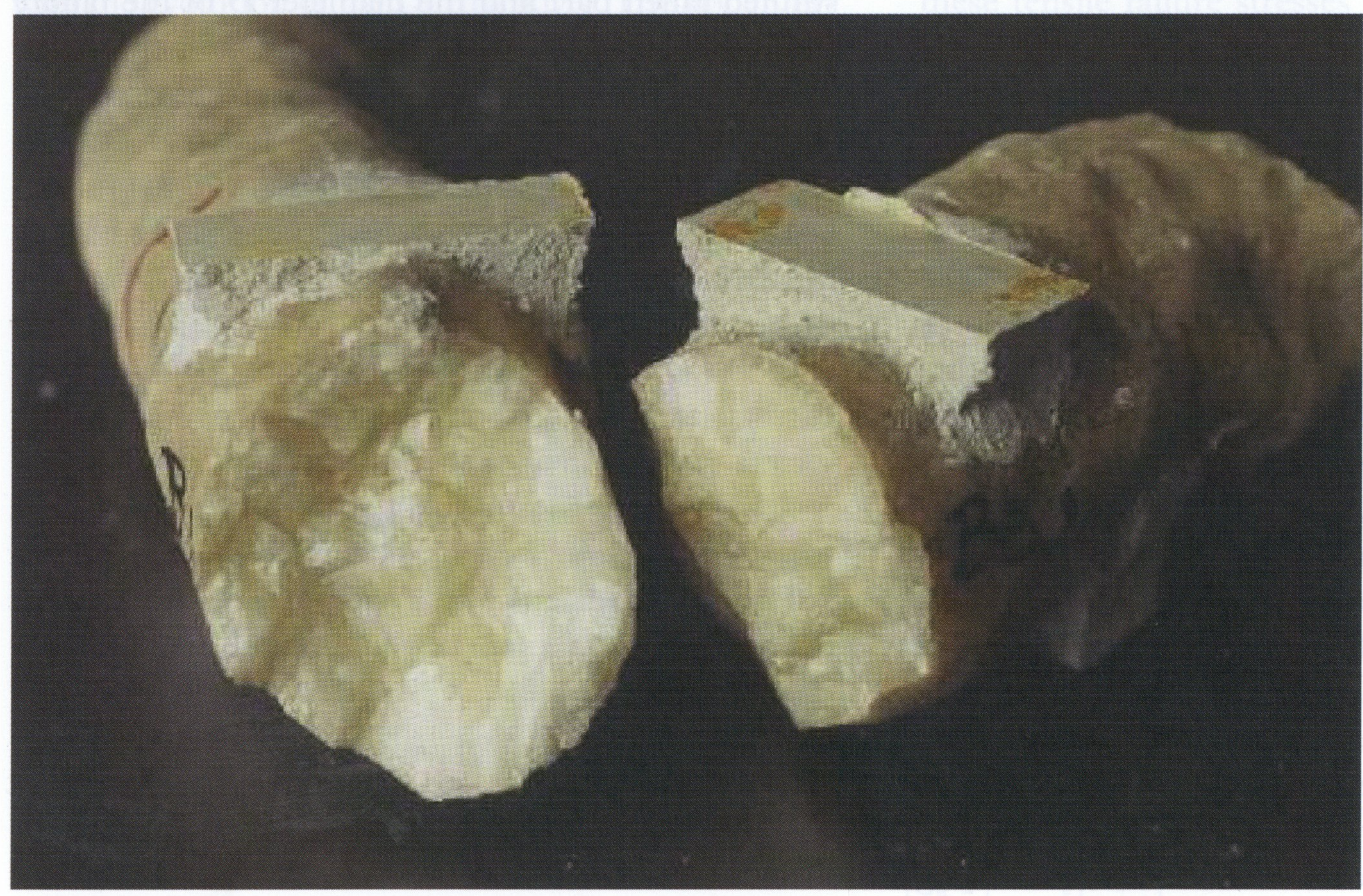

Photo 3. A failure section after bending test.

The parameters considered in the computations are: $H$ Height of the speleothem over the failure section [m]

$D$ In-site measured diameter of the failure section [m] $r \quad$ Radius of the failure section $[\mathrm{m}]$

$S \quad$ Area of the failure section $\left[\mathrm{m}^{3}\right]$

$E$ Young's modulus of the speleothem material $\left[\mathrm{N} / \mathrm{m}^{3}\right]$

$I \quad$ Inertia of the failure section $\left[\mathrm{m}^{4}\right]$ 
$V \quad$ Volume of the speleothem $\left[\mathrm{m}^{3}\right]$

$m$ Mass of the speleothem $[\mathrm{kg}]$

$F$ Inertia forces applied on the speleothem at the mid height $[\mathrm{N}]$

$M$ Bending moment due to inertia forces in the failure section $[\mathrm{Nm}]$

$\sigma_{u} \quad$ Failure stress in tension [MPa]

$a_{g} \quad$ Peak ground acceleration $\left[\mathrm{m} / \mathrm{s}^{2}\right]$

$f_{P} \quad$ Fundamental frequency of the speleothems $[\mathrm{Hz}]$

The fundamental frequency of a cantilever beam is given by the following equation:

$$
f_{P}=\frac{1}{\pi} \sqrt{\frac{3 E D^{2}}{16 \rho H^{4}}}
$$

The natural frequency of the speleothems are then between $20 \mathrm{~Hz}$ and $6815 \mathrm{~Hz}$ (Table 3). As the energy of an earthquake is essentially released within a frequency range lower than $20 \mathrm{~Hz}$, the speleothems can be considered as rigid bodies in a first approximation and submitted to the ground acceleration without amplification.

The ground acceleration that leads to the failure of a speleothem as a function of its geometry and failure stress is obtained through the following relationships:

$$
\begin{aligned}
& \sigma_{u}=\frac{M r}{I}=F \frac{H}{2} \frac{4}{\pi r^{3}}=m a_{g} \frac{2 H}{\pi r^{3}}=2 \rho \frac{H^{2}}{r} a_{g} \\
& a_{g}=\frac{1}{4} \frac{D}{\rho H^{2}} \sigma_{u}
\end{aligned}
$$

If a failure stress of $0.4 \mathrm{MPa}$ is considered in the calculation, the acceleration needed to break the speleothems by flexion are between $2 \mathrm{~m} / \mathrm{s}^{2}$ and $667 \mathrm{~m} / \mathrm{s}^{2}$ (Table 3). This ground acceleration decrease with an increasing $H / D$ ratio. Values lower then 10 $\mathrm{m} / \mathrm{s}^{2}$ are obtained for $H / D$ ratio higher then around 8 . The highest values of ground accelerations are obtained for very small dimensions speleothems.

\section{Discussion on the mechanical model}

The geometry of the broken speleothems in the Hotton cave was defined by only two parameters; the length of the reconstituted speleothems (some of them were broken in 3 or 4 parts) and one diameter of the failure section. The main hypotheses of the previous calculations are that the cross sections of the speleothem are circular with a diameter D measured in the cave and that this section is constant along the height of the speleothem. It is obvious that the cross sections along the height of the speleothem exhibit a non-circular shape (Figure 2 and Photo 3). A more
Table 3. Dimensions of broken speleothems in the Hotton cave,

\begin{tabular}{|c|c|c|c|c|c|c|}
\hline$N^{o}$ & $H$ & $D$ & $H / D$ & $m$ & $a$ & $f$ \\
\hline & $\mathrm{m}$ & $\mathrm{m}$ & & $\mathrm{kg}$ & $\mathrm{m} / \mathrm{s}$ & $\mathrm{Hz}$ \\
\hline 1 & 0.520 & 0.27 & 1.9 & 74.432 & 40 & 408 \\
\hline 2 & 0.180 & 0.10 & 1.8 & 3.534 & 123 & 1262 \\
\hline 3 & 0.100 & 0.08 & 1.3 & 1.257 & 320 & 3271 \\
\hline 4 & 0.280 & 0.06 & 4.7 & 1.979 & 31 & 313 \\
\hline 5 & 0.260 & 0.11 & 2.4 & 6.177 & 65 & 665 \\
\hline 6 & 0.315 & 0.06 & 5.3 & 2.227 & 24 & 247 \\
\hline 7 & 0.300 & 0.06 & 5.0 & 2.121 & 27 & 273 \\
\hline 8 & 0.140 & 0.03 & 4.7 & 0.247 & 61 & 626 \\
\hline 9 & 0.160 & 0.08 & 2.0 & 2.011 & 125 & 1278 \\
\hline 10 & 0.500 & 0.06 & 8.3 & 3.534 & 10 & 98 \\
\hline 11 & 0.570 & 0.08 & 7.6 & 6.295 & 9 & 94 \\
\hline 12 & 0.240 & 0.11 & 2.2 & 5.702 & 76 & 781 \\
\hline 13 & 0.190 & 0.06 & 3.2 & 1.343 & 66 & 680 \\
\hline 14 & 0.070 & 0.08 & 0.9 & 0.880 & 653 & 6676 \\
\hline 15 & 0.060 & 0.06 & 1.0 & 0.424 & 667 & 6815 \\
\hline 16 & 0.350 & 0.10 & 3.5 & 6.872 & 33 & 334 \\
\hline 17 & 0.230 & 0.07 & 3.3 & 2.213 & 53 & 541 \\
\hline 18 & 0.160 & 0.07 & 2.3 & 1.539 & 109 & 1118 \\
\hline 19 & 0.310 & 0.09 & 3.4 & 4.930 & 37 & 383 \\
\hline 20 & 0.150 & 0.10 & 1.5 & 2.945 & 178 & 1817 \\
\hline 21 & 0.250 & 0.08 & 3.1 & 3.142 & 51 & 523 \\
\hline 22 & 0.350 & 0.27 & 1.3 & 50.099 & 88 & 901 \\
\hline 23 & 0.400 & 0.07 & 5.7 & 3.848 & 18 & 179 \\
\hline 24 & 0.360 & 0.25 & 1.4 & 44.179 & 77 & 789 \\
\hline 25 & 0.210 & 0.07 & 3.0 & 2.020 & 63 & 649 \\
\hline 26 & 0.260 & 0.06 & 4.3 & 1.838 & 36 & 363 \\
\hline 27 & 0.180 & 0.15 & 1.2 & 7.952 & 185 & 1893 \\
\hline 28 & 0.350 & 0.10 & 3.5 & 6.872 & 33 & 334 \\
\hline 29 & 0.250 & 0.10 & 2.6 & 4.430 & 61 & 621 \\
\hline 30 & 0.200 & 0.07 & 2.9 & 1.924 & 70 & 716 \\
\hline 31 & 0.280 & 0.11 & 2.7 & 6.061 & 54 & 548 \\
\hline 32 & 0.540 & 0.07 & 8.3 & 4.480 & 9 & 91 \\
\hline 33 & 0.400 & 0.10 & 4.0 & 7.854 & 25 & 256 \\
\hline 34 & 1.000 & 0.05 & 20.0 & 4.909 & 2 & 20 \\
\hline
\end{tabular}
their natural frequency ( $f$ ) and the ground acceleration (a) necessary for their rupture.

realistic model can be built to estimate the influence of these geometrical uncertainties.

Now, we consider that the failure cross section of the speleothem is circular of diameter $D_{u}$ which is the real dimension that influences the resistance of the failure section. $D_{u}$ is used to calculate the resistance of the speleothem. The geometry of the speleothem is modelled as a cylinder of height $\mathrm{H}$ (the measured height from the fallen part of the speleothem) and of diameter $\mathrm{D}_{\text {mean }}$ (Figure 7). The diameter is fixed so that the cylinder has the same mass as the real speleothem.

We have then:
$\mathrm{D}_{\mathrm{u}}, \mathrm{r}_{\mathrm{u}}$
Diameter (radius) of the failure section [m]
$\mathrm{D}_{\text {mean }}, \mathrm{r}_{\text {mean }}$ Mean diameter (radius) of the speleo- them $[\mathrm{m}]$ 
While in the previous case the centre of gravity of the broken part from the speleothem was considered at mid-height, another case was envisaged with the centre of gravity at $\alpha \mathrm{H}$ from bottom. $\alpha$ is a non-dimensional parameter, ranging from zero (failure section level) to one (top of the speleothem). This position affects the value of the bending moment in the failure section when the speleothem is submitted to a ground movement.

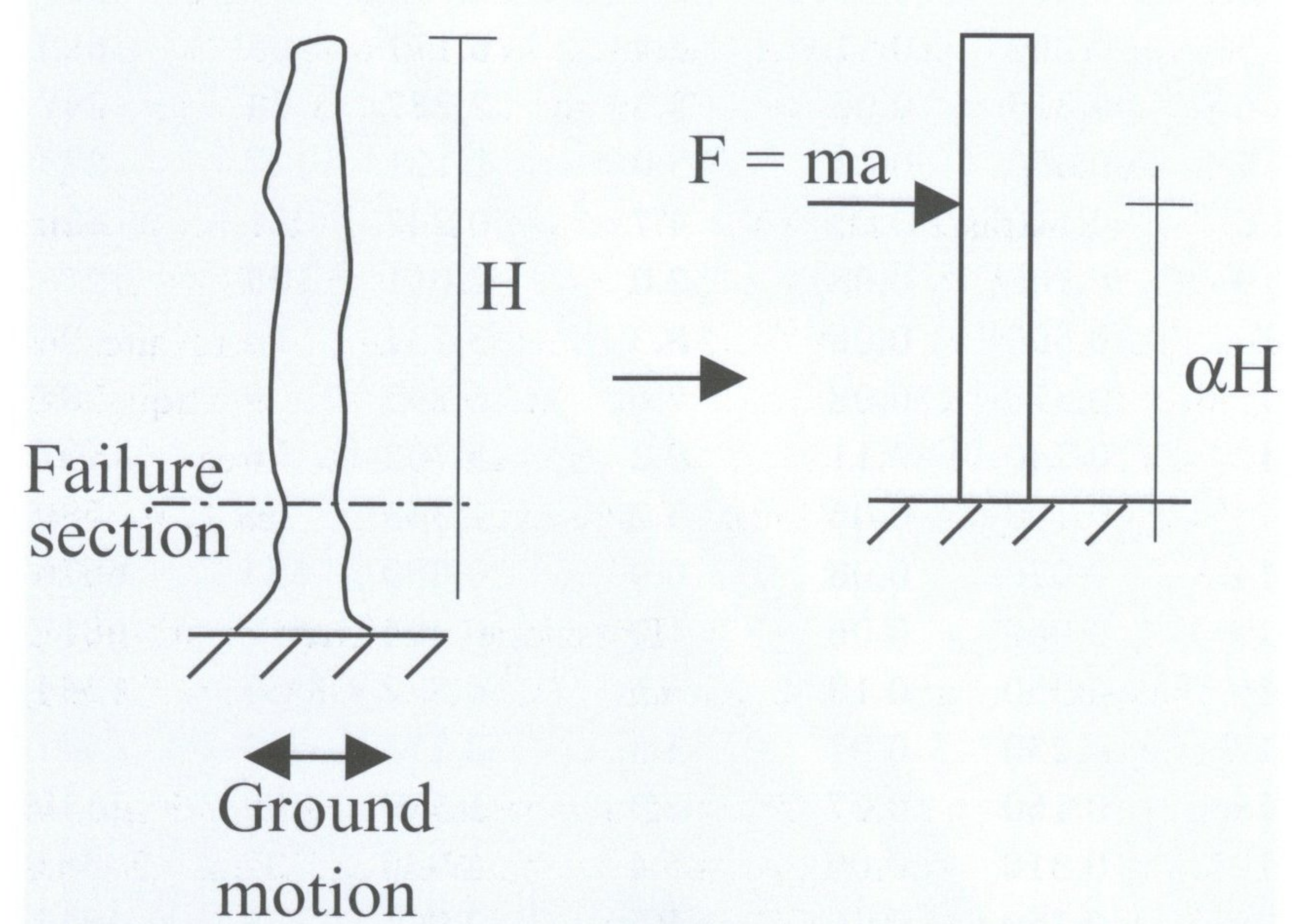

Fig. 6. Elevation view of a speleothem and model.

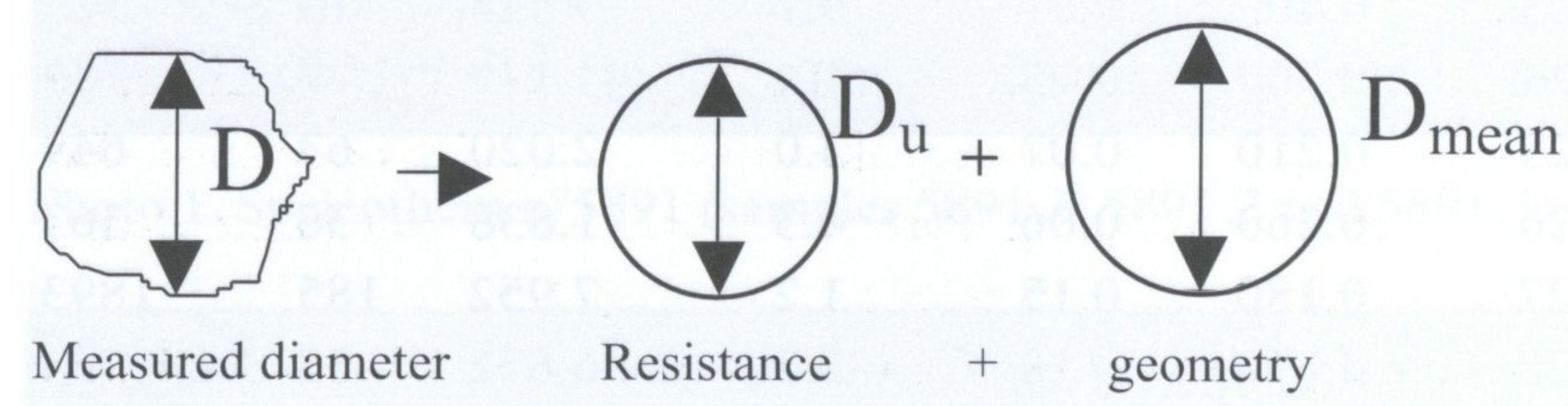

Fig. 7. Failure section and cross section models.

Local geometrical imperfections can lead to some stress concentrations. The value of the stress concentration factor $\psi$, ratio between the maximum stress $\sigma_{\max }$ and the mean stress $\sigma_{m}$, depends on the type of notch. We will not consider the case of an already initiated crack, for which $\psi$ can be as high as 10 or 20, but simply the notch effect corresponding to an irregular surface aspect which is commonly observed. It is similar to a semicircular notch (of radius $\rho$ ) having the shape shown in Figure 8, for which tension tests on mortar specimens have indicated a value around 2 [Massonnet 1962].

Considering the stress concentration factor, the new position of the inertia forces and the two different diameters $\mathrm{D}_{\mathrm{u}}$ and $\mathrm{D}_{\text {mean }}$ of the cross section, it is possible to rewrite the formulas (2) and (3):

$$
\begin{aligned}
\sigma_{u} & =\psi \frac{M r_{u}}{I}=\psi F \alpha H \frac{4}{\pi r_{u}{ }^{3}}=\psi m a_{g}{ }^{*} \frac{4 \alpha H}{\pi r_{u}{ }^{3}} \\
& =4 \alpha \rho \frac{H^{2} r_{\text {mean }}{ }^{2}}{r_{u}{ }^{3}} \psi a_{g}{ }^{*}
\end{aligned}
$$

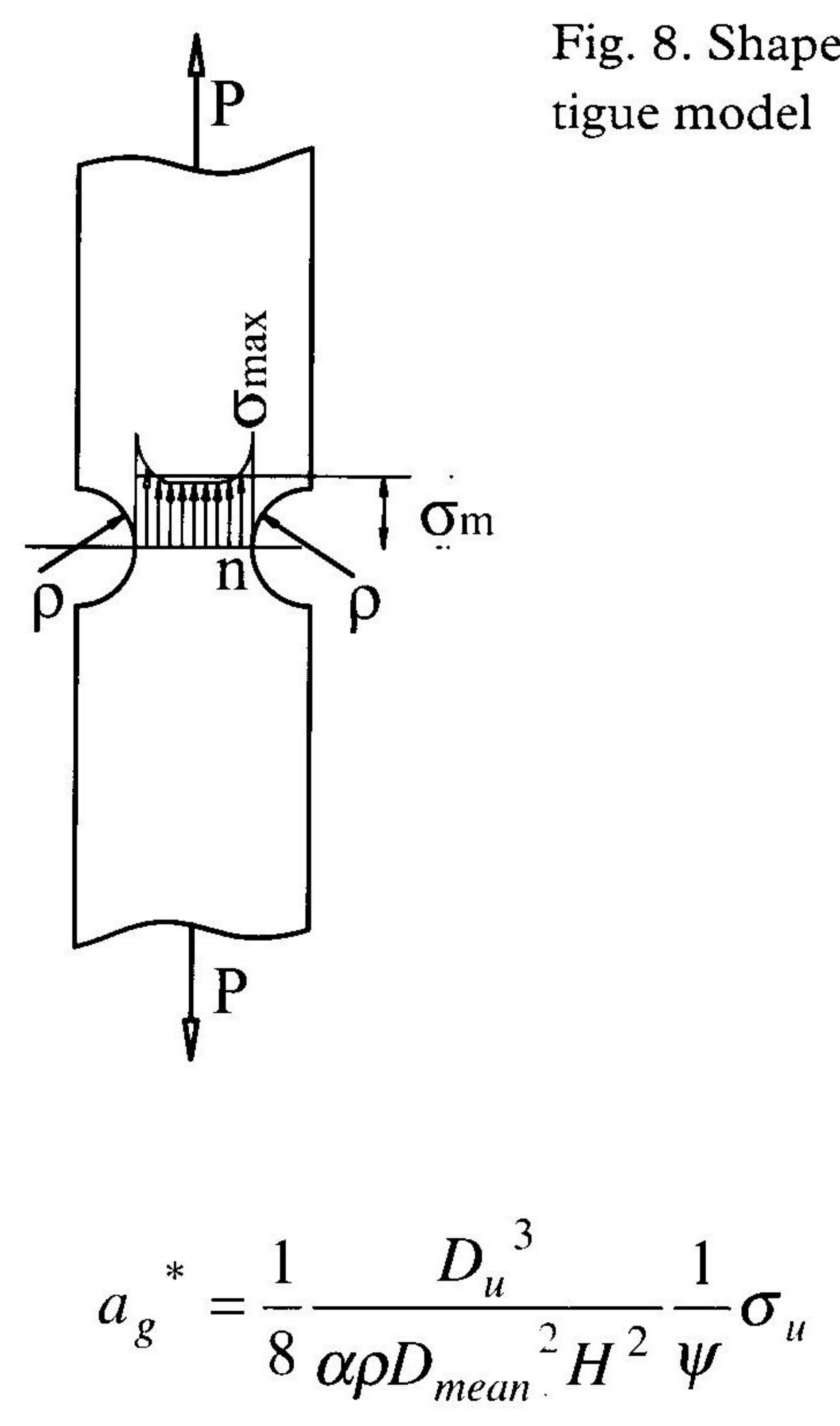

The ratio of the ground accelerations that leads to the failure of a speleothem obtained with the two different models is :

$$
\frac{a_{g}{ }^{*}}{a_{g}}=\frac{0.5}{\alpha} \frac{\left(\frac{D_{u}}{D}\right)^{3}}{\left(\frac{D_{\text {mean }}}{D}\right)^{2}} \frac{1}{\psi}
$$

The diameter variation of the sections along the speleothem can reasonably be estimated from $20 \%$ to $30 \%$. The diameter which is taken into account to evaluate the resistance can vary about $10 \%$ around the measured value. And the level of the resultant inertia force can be estimated to be between $0.3 \mathrm{H}$ and $0.7 \mathrm{H}$.

From the formula (6), we obtain a ratio

$$
\frac{a_{g}{ }^{*}}{a_{g}}=\frac{0.5}{0.7} \frac{(0.9)^{3}}{(1.3)^{2}} \frac{1}{2}=\frac{1}{6.5} \text {. }
$$

Taking into account the geometry uncertainties and a possible stress concentration, the accelerations needed to break the speleothems by flexion can thus decrease to values between $0.3 \mathrm{~m} / \mathrm{s}^{2}$ and $100 \mathrm{~m} / \mathrm{s}^{2}$.

\section{Conclusions}

The main conclusion of our mechanical tests and modelling results is that horizontal acceleration values needed to break the speleothems of Hotton cave are very scattered from $0.03 \mathrm{~g}$ to $10 \mathrm{~g}$. Even if low accelerations were detected, globally the values are much higher than the peak ground acceleration expected from earthquakes. If the failure happens due 
to shear and not bending, the acceleration required would even be stronger. If vertical accelerations had been considered, the horizontal ones would have been reduced at most by $30 \%$ to $50 \%$ but still the conclusions would remain the same.

These results are obtained considering a tensile failure stress of 0.4 MPa in our computations, which is the minimum measured resistance. This measurement was however determined on stalagmite samples which were already broken inside the Hotton cave. It is reasonable to consider that the resistance values at the break could be lower than 0.4 MPa. Moreover, the speleothems are not cylindrical and the section variations could lead to a decrease in the acceleration values required to break the speleothems.

Computations showed that these effects can reduce the accelerations required for failure by a factor of 6.5 , which is not enough to explain the disagreement between computed accelerations and expected earthquake accelerations for all the broken speleothems in Hotton cave.

The understanding of speleothem fall in Hotton cave requires several aspects to be clarified. One problem can be the adequacy of the modelling used to represent the dynamic behaviour of speleothems. Discontinuities inside the material like cleavages, stratifications,... play also a role during the speleothem deformation. Future research efforts should be focused on in-situ measurements of the response of speleothems to vibrations and on the study of the rupture mechanism at the grain size.

\section{Acknowledgement}

This work has been supported by the FRFC Belgium project 2450297.

\section{References}

Bini A., Quinif Y., Sules O., Uggeri A., 1992. Evidences de tectonique récente dans les grottes du M. Campo de Fiori (Lombardie, Italie). Karstologia $19: 23-30$.

Delaby S., 1999. Etude statistique de l'enregistrement paléosismique par les spéléothèmes. L'exemple de la Grotte de Hotton
(Belgique). 'Karst 99'. Etudes de géographie physique, travaux 1999 - Suppl.nE XXVIII, CAGEP, Université de Provence : 73 76.

Delaby S., 2001. Paleoseismic investigations in Belgium caves. . In press: Cahier du Centre Européen de Géodynamique et de Sismologie, Vol 18: $45-48$.

Forti P., Postpischl D., 1979, a, b. Derivazione di dati neotettonici $\mathrm{da}$ analisi di concrezioni alabastrine, $1 \mathrm{E}$ contributo. Analisi statistica delle stalagmiti del sistema carsico Fiume-Vento (S. Vittore Genga - Ancona). CNR - Progetto Finalizzato Geodinamica 251.

Forti P., Postpischl D., 1980. Neotectonic data from stalagmites : sampling and analysis techniques. European Regional Conference on Speleology Sofia, CNR - Progetto Finalizzato Geodinamica, 351 Sofia, 2, 34-39.

Forti P., Postpischl D., 1984. Seismotectonic and paleoseismic analysis using karst sediments. Marine Geology 55, 145-161.

Forti P., Postpischl D., 1986. May the growth axis of stalagmites be considered as recorders of historic and prehistoric earthquakes? Preliminary results from the Bologna karst area (Italy). Int.Symp.Engineering Geology Problems in Seismic area 1, Bari, 1, 183-193.

Forti P., Postpischl D., 1988a. Datazione radiometrica di eventi palaeosismici. in : M. Unguendoli Ed., Studi e Ricerche CUSL, Bologna.

Forti P., Postpischl D., 1988b. Seismotectonics and radiometric dating of karst sediments. Proc.Hist.Seismol.Central Eastern Mediterranean Region ENEA, Roma, 321-332.

Gilli E., 1986. Néotectonique dans les massifs karstiques, un exemple dans les Préalpes de Nice, la grotte des Deux Gourdes. Karstologia 8, 50-52.

Gilli E., Levret A., Sollogoub P., Delange P., 1999. Research on the February 18, 1996 earthquake in the caves of Saint-Paul-de-Fenouillet area (eastern Pyrenees, France). Geodinamica Acta Karst and tectonics : Han-98, 12, 3-4 : 143-158.

Lemeille F., Cushing M., Carbon D., Grellet B., Bitterli T., Flehoc C., Innocent C., 1999. Co-seismic ruptures and deformations recorded by speleothems in the epicentral zone of the Basel earthquake. Geodinamica Acta - Karst and tectonics : Han-98, 12, 3-4 : 179-192.

Massonnet Ch., Résistance des Matériaux, Ed. Dunod 1962,pp 56-57

Moretti A., Vulcano A., 1999. Uso di speleotemi quali possibli indicatori della massima accelerazione sismica al sito. GEOITALIA, $2^{\circ}$ Forum FIST, Vol 1. 355-357.

Postpischl D., Ahostini S., Forti P., QuinifY., 1991. Palaeoseismicity from karst sediments : the 'Grotta del Cervo' cave case study (Central Italy). Tectonophysics 193 : 33-44.

Quinif Y., 1996. Enregistrement et datation des effets sismotectoniques par l'étude des spéléothèmes. Annales de la Société Géologique de Belgique 119, 1 : 1-13. 